\title{
Salicylic acid and potassium nitrate promote flowering through modu- lating the hormonal levels and protein pattern of date palm Phoenix dactylifera 'Sayer' offshoot
}

\author{
Hussein J. SHAREEF ${ }^{1,2}$
}

Received April 21, 2019; accepted October 14, 2019.

Delo je prispelo 21. aprila 2019, sprejeto 14. oktobra 2019.

Salicylic acid and potassium nitrate promote flowering through modulating the hormonal levels and protein pattern of date palm Phoenix dactylifera 'Sayer' offshoot

Abstract: Salicylic acid enhances the flowering process in the plant by creating new proteins under salinity stress. The study was to determine the role of salicylic acid $(500 \mathrm{ppm})$ and potassium nitrate $(1500 \mathrm{ppm})$, on flowering of date palm 'Sayer' offshoots under salinity effect. Application of salicylic acid increased the number of clusters, the number of new leaves, the content of carbohydrates, ascorbic acid, indoleacetic acid, zeatin, gibberellin, and abscisic acid significantly under salinity compared with control. Although the measured parameters were the highest in plants treated with salicylic acid, there was no distinction among potassium nitrate treatment under saltwater, and salicylic acid treatment with saltwater. Salicylic acid and potassium nitrate treatment demonstrated some amazing contrasts in protein patterns in light of gel electrophoresis. Plants treated with salicylic acid with fresh water and with saltwater showed five and six protein bands, respectively, that differed in the molecular mass of one polypeptide compared to control with freshwater. However, there was a difference in the molecular mass of two polypeptides compared to control with salt water, which showed six bands. In contrast, potassium nitrate application showed five protein bands, whether with freshwater or with saltwater. The findings could facilitate to elucidate the flowering mechanisms in date palm.

Key words: abscisic acid; clusters number; zeatin; electrophoresis; gibberellin; indoleacetic acid
Salicilna kislina in kalijev nitrat pospešujeta cvetenje stranskih poganjkov dateljeve palme (Phoenix dactylifera 'Sayer') $\mathrm{z}$ moduliranjem ravni hormonov in vzorca proteinov

Izvleček: Salicilna kislina pospešuje cvetenje preko tvorbe novih proteinov $\mathrm{v}$ razmerah slanostnega stresa. Namen raziskave je bil določiti vlogo salicilne kisline (500 ppm) in kalijevega nitrata $(1500 \mathrm{ppm})$ na cvetenje stranskih poganjkov dateljeve palme ('Sayer') v razmerah slanosti. Uporaba salicilne kisline je značilno povečala število stranskih poganjkov, število novih listov, vsebnost ogljikovih hidratov, askorbinske kisline, indolocetne kisline, zeatina, giberelina in abscizinske kisline $\mathrm{v}$ razmerah slanosti $\mathrm{v}$ primerjavi s kontrolo. Čeprav so imeli vsi merjeni parametri največje vrednosti pri obravnavanju s salicilno kislino, ni bilo razlike $\mathrm{v}$ obravnavanjih $\mathrm{s}$ kalijevim nitratom in salicilno kislino $\mathrm{v}$ istih razmerah. Obravnavanja s salicilno kislino in kalijevim nitratom so imela velike razlike $\mathrm{v}$ vzorcu proteinov, določenem $\mathrm{z}$ gelsko elektroforezo. Rastline, ki so bile tretirane s salicilno kislino, sladko in slano vodo so imele pet oziroma šest proteinskih trakov, ki so se razlikovali v molekulski masi enega izmed polipeptidov v primerjavi s kontrolo, kjer je bilo samo obravnavanje s sladko vodo. Kakorkoli, v primerjavi s kontrolo, kjer je bilo obravnavanje samo s slano vodo in je bilo šest proteinskih trakov, je bila razlika v molekulski masi dveh polipeptidov. Obravnavanje samo s kalijevim nitratom je pokazalo samo pet proteinov, ne glede na obravnavanje s slano ali sladko vodo. Ti izsledki bi lahko pomagali razjasniti mehanizem cvetenja pri dateljevi palmi.

Ključne besede: abscizinska kislina; število poganjkov; zeatin; elektroforeza; giberelin; indolocetna kislina 


\section{INTRODUCTION}

Date palm (Phoenix dactylifera L.) is usually exposed to abiotic stresses in an arid and semi-arid region. Notably, high temperatures, the shortage of irrigation water, and soil salinity are the real constraining variables to productivity (Allbed et al., 2017). The production of fruits is restricted in the extreme conditions. In any case, their development and yield profitability are reduced (Moustafa et al., 2018), where the yield reduced to half at $18 \mathrm{dS} \mathrm{m}^{-1}$ and $100 \%$ at $32 \mathrm{dS} \mathrm{m}^{-1}$ (Elsadig et al., 2017). The production of date palm fruits relies upon the number of clusters and the success of the pollination process. Flowering in date palm is delayed when presented to unforgiving natural conditions. Date palm flowering is a complex process in which numerous natural factors and the physiological material of the plant interact. However, the transformation of the axillary buds to floral buds in the date palm relies upon a high sugar level and a low nitrogen $\mathrm{C} / \mathrm{N}$ ratio. For this situation, the role of the ecological conditions includes a substantial impact on the regulation of this quantitative relation, particularly the impact of salinity, whether the salinity of the soil or water system conditions (Shareef, 2016). We have observed earlier that foliar application of salicylic acid on offshoots induced flowering in date palm under salt stress, especially at the early stage (Shareef et al., 2017).

Salicylic acid (2-hydroxybenzoic acid) (SA), is thought to activate general plant resistance ordinarily related to activation of defense genes (Tamaoki et al., 2013). Moreover, SA has a specific role in plant growth, induction of flowering, and uptake of ions. Thus, it has an essential role in the regulation of flowering (Wada \& Takeno, 2013). The formation of the buds as a result of the SA application is unusual as SA changes the synthesis and signaling pathways of plant hormones, like jasmonic acid, ethylene, and auxin (IAA) (Vlot et al., 2009). Auxin, abscisic acid, and zeatin gradually decrease during flowering in date palm leaves in early varieties and then rise after flowering while the gibberellin (GA3) increased (Cheruth et al., 2015). Gibberellins accordingly are hormones responsible for dynamics in the survival and persistence of plants (Lymperopoulos et al., 2018). The effects on the phase of plant development and blossoming at the suitable season increased plant production. The interaction of environmental signals with endogenous biological process signals the main mechanisms which control flowering time in plant and are stimulated by rising SA (Zhang et al., 2018). Khayyat et al. (2018) found that the stimulation of the flowering of the saffron plant was successful using $2 \mathrm{mM}$ SA or $1000 \mathrm{ppm}$ potassium.
Under the water shortage conditions, leaf stomata do not function actively in plants with potassium deficiency and, therefore, cause excessive water loss ( Farooq et al., 2015). Potassium (K) plays a vitally role in the physiological processes of photosynthesis, in the formation of carbohydrates and proteins, the transfer of water and nutrients, in use of nitrogen $(\mathrm{N})$, and the stimulation of early plant growth (Lakudzala, 2013). In plant tissues, the transport of water, nutrients, and carbohydrates is enhanced by potassium application (Safar-Noori et al., 2018). Potassium ions induce gene expression in light of environmental changing (Zhang et al., 2018a). Gene expression drives the biological process and stress properties. It is, therefore responsible for subsequent translation modifications of the pure nucleus proteins and sometimes methylation of deoxyribonucleic acid (Zhang et al., 2018b). The process of flowering is controlled by a group of genes made up of gene expression (Yan et al., 2019).

This study aimed to check whether the exogenous use of salicylic acid (SA) or potassium nitrate $\left(\mathrm{KNO}_{3}\right)$ will positively influence the growth and formation of flower buds in the late flowering date palm.

\section{MATERIALS AND METHODS}

\subsection{EXPERIMENT FIELD}

The experiment was equipped at the General Authority of Palm station, Burjysia, Basrah, Iraq (latitude $30^{\circ} 22^{\prime} 6.294$ " $\mathrm{N}$ and longitude $47^{\circ} 36^{\prime} 39.639^{\prime \prime}$ ) at $26 \mathrm{~km}$ of Basrah center, in 2017 and 2018 growing season. In the experiment, 30 plants used, Sayer date palm cultivar was five years old, planted on $5 \times 5 \mathrm{~m}$ in sandy loam. The drip irrigation system was used. The normal EC value for soil was $12 \mathrm{dS} \mathrm{m}^{-1}$. The average temperature of the experiment months was in October $26.2^{\circ} \mathrm{C}$, November $20.4^{\circ} \mathrm{C}$, December $14.4^{\circ} \mathrm{C}$, January $12.2^{\circ} \mathrm{C}$, February $14.1^{\circ} \mathrm{C}$, March $18.1^{\circ} \mathrm{C}$, and April $23.8^{\circ} \mathrm{C}$. Plants were treated with saltwater and freshwater on April $1^{\text {st }}$ in season 2017, according to the block design during the six months before the treatments, and continued until the samples were taken on April $1^{\text {st }}$ in the season of 2018 after the flowers were completed in this variety. The plants were treated with foliar treatment once, with one plant for each replicate on October $1^{\text {st }}$ in the season of 2017 as follows: only spray water $\left(0 \mathrm{dS} \mathrm{m}^{-1}\right)+$ irrigation with freshwater (EC water $1.5 \mathrm{dS} \mathrm{m}^{-1}$ ) (control); spray only with water + irrigate with salt water (EC $8 \mathrm{dS}$ $\mathrm{m}^{-1}$ ) (control); foliar spray of $500 \mathrm{ppm}$ salicylic acid (SA) + irrigation with fresh water; foliar spray of SA at 
500 ppm + irrigated with saltwater; foliar spray with potassium nitrate $\left(\mathrm{KNO}_{3}\right) 1500 \mathrm{ppm}+$ irrigated with freshwater; foliar spray with $\mathrm{KNO}_{3} 1500$ ppm + irrigated with saltwater. On the $1^{\text {st }}$ of April in the season of 2018, the data on plant parameters described in the following subchapters were recorded.

\subsection{NUMBER OF CLUSTERS}

The date palm starts to flower usually in February until April. The flowering is completed at the Hillawi cultivar, usually in April. The number of clusters was determined by calculating the number of clusters per plant to different treatments in April one time.

\subsection{THE NUMBER OF NEW LEAVES}

At the beginning of October, the number of leaves was assessed before the treatment time for each plant. The number of new leaves is completed in date palm in the spring. Therefore, at the beginning of April, the number of newly formed leaves was determined according to the following formula:

New leaves $=$ Total of leaves on April - Total of leaves before treatment.

\subsection{CARBOHYDRATE ANALYSIS}

Soluble carbohydrates were determined after Yemm \& Willis (1954). Samples of fresh pinnae were weighed $(0.2 \mathrm{~g})$ and homogenized using $70 \%$ ethanol. Then they were filtered, and the use of benzene removed pigments. An aliquot of $0.2 \mathrm{ml}$ of leaf extract was added to $1.0 \mathrm{ml}$ of $5 \%$ phenol $+5 \mathrm{ml} \mathrm{H}_{2} \mathrm{SO}_{4}$ $95 \%$ to react in a water bath for $10 \mathrm{~min}$ at $100^{\circ} \mathrm{C}$. Soon after, the test tube was cooled in an ice bath, and then the absorbance was read at $620 \mathrm{~nm}$.

\subsection{ASCORBIC ACID (ASA) CONTENT}

AsA content was determined by employing a slightly changed methodology of Luwe et al. (1993) in which $0.5 \mathrm{~g}$ of green leaf pieces were ground in liquid nitrogen and afterward homogenized in $1 \%$ cold trichloroacetic acid. The homogenate was then centrifuged at $12,000 \times \mathrm{g}$ for 20 minutes at $4{ }^{\circ} \mathrm{C}$, and the supernatant $(50 \mu \mathrm{l})$ blended with $100 \mathrm{mM}$ potassium phosphate buffer, and ascorbate estimated at $265 \mathrm{~nm}$.

\subsection{HORMONES ANALYSIS}

Five $g$ of a fresh leaf tissue sample, which was homogenized in $70 \%$ methanol was stirred overnight at $4{ }^{\circ} \mathrm{C}$. The extract was filtered through Whatman filter paper (No. 1) and evaporated under vacuum. The $\mathrm{pH}$ of the aqueous phase was adjusted to 8.5 using $0.1 \mathrm{M}$ phosphate buffer. Later the aqueous phase was partitioned using methanol twice. The methanol phase was removed by a rotary evaporator. The aqueous phase $\mathrm{pH}$ was adjusted to 2.5 , using $1 \mathrm{~N}$ hydrochloric acid (HCI). Phytohormones were determined by the injection of the concentrate into a reversed-phase HPLC, C18 column in an isocratic elution mode utilizing a portable stage comprising of acetone: water (26:74) with $30 \mathrm{mM}$ phosphoric acid as per Tang et al. (2011). The $\mathrm{pH}$ was kept up at 4, utilizing $1 \mathrm{~N}$ sodium hydroxide. A temperature was kept upt at $25^{\circ} \mathrm{C}$. The flux rate was $0.8 \mathrm{ml} \mathrm{min}^{-1}$, and the elution of the phytohormones was observed at 208, 265, 270, and $280 \mathrm{~nm}$ for indoleacetic acid, abscisic acid, gibberellins, and zeatin, respectively.

\subsection{EXTRACTION OF PROTEINS AND GEL ELECTROPHORESIS}

Proteins were extracted by homogenizing the $333 \mathrm{mg}$ of solidified dried leaf to $1 \mathrm{ml}$ of extraction cradle $[0.2 \mathrm{M}$, tris-hydroxymethyl aminomethane (Tris) + $0.001 \mathrm{M}$ ethylene diamine tetra acetic acid + $\left(\mathrm{Na}_{2}+\right.$ EDTA $)+12 \%$ glycerol $+0.01 \mathrm{M}$ dithio threitol (DTT) $+0.05 \mathrm{mM}$ phenyl methyl sulfonyl fluoride (PMSF)] by utilizing the mortar and pestle. At that point the samples were centrifuged at $15,000 \times \mathrm{g}$ for 15 min. Splitting buffer consisted of $0.125 \mathrm{M}$ Tris $\mathrm{HCl}$ $(\mathrm{pH} 6.8)+4 \%$ SDS $+20 \%$, glycerol $+10 \%$ b-mercapto ethanol $+0.01 \%$ bromo phenol blue. Protein samples were denaturized by bubbling in the water bath at $90{ }^{\circ} \mathrm{C}$ for $3 \mathrm{~min}$. Protein electrophoresis was performed in an irregular SDS polyacrylamide gel, as indicated by a strategy depicted by Laemmli (1970).

\subsection{STATISTICAL ANALYSIS}

Randomized completely block design of six treatments of salicylic acid and potassium nitrate replicated five times were utilized. Experimental data on all factors were analyzed by ANOVA. SPSS variant 19.0 (SPSS, Chicago, IL), and Duncan test were used for different correlations treatments considered at the $p \leq$ 0.05 levels. 


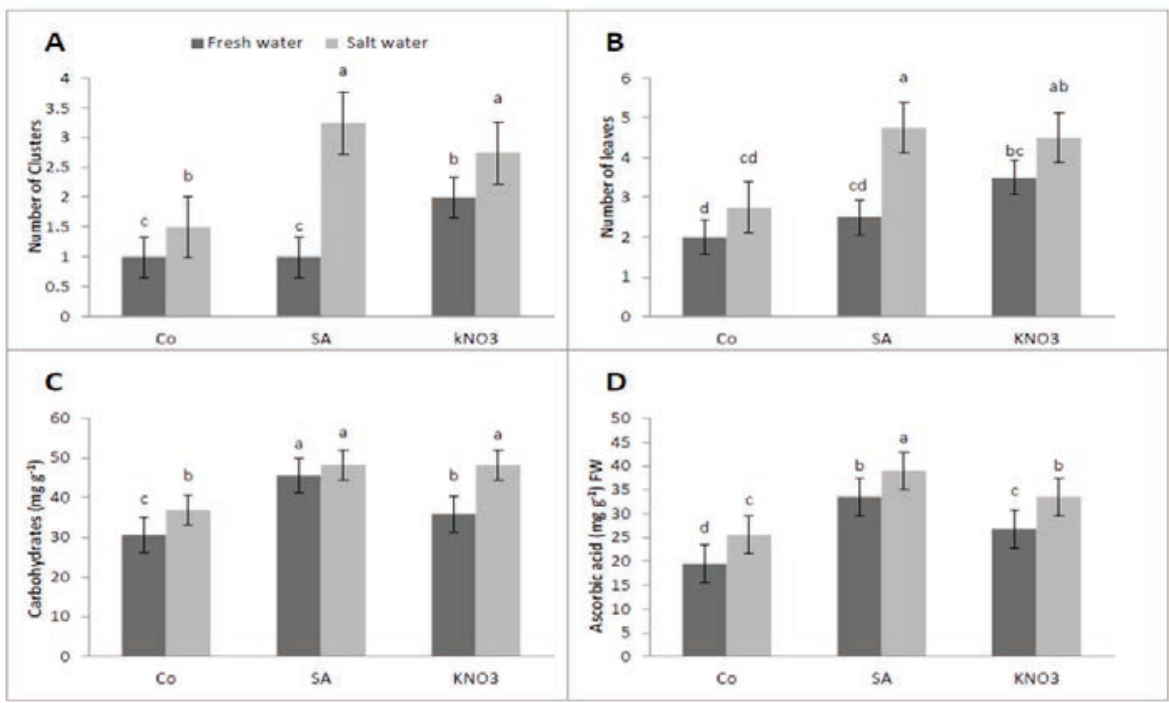

Figure 1: Salicylic acid and potassium nitrate effects on the number of clusters (A), number of new leaves (B), carbohydrates (C), and ascorbic acid (D)content in leaves of date palm offshoots after irrigated with salt water or with fresh water. The means of five replicates \pm SE are presented. Bars with different letters are significantly different at $p \leq 0.05$ after a Duncan correction.

\section{RESULTS}

\subsection{EXOGENOUS UTILIZATION OF SA AND $\mathrm{KNO}_{3}$ PROMOTES FLOWERING, NUMBER OF NEW LEAVES, CARBOHYDRATES AND ASCORBIC ACID}

The highest flowering rate was observed through SA treatment in salinity conditions followed by $\mathrm{KNO}_{3}$ under the same conditions, whereas the lowest clusters number was found in control irrigated with fresh water, compared with saltwater (Fig. $1 \mathrm{~A}$ ). The number of new leaves was fundamentally influenced by treatments; however, there was no difference between control, freshwater, and saltwater. Although the highest value of this variable was seen in plants treated with SA, there was no distinction among $\mathrm{KNO}_{3}$ treatment under saltwater and SA treatment with salt water (Fig. 1 B). Application of both $\mathrm{KNO}_{3}$ and SA treatments significantly increased carbohydrates in leaves under salt stress; there was no difference among treatments in this trait (Fig. $1 \mathrm{C})$. Ascorbic acid content under salt stress was higher than with freshwater in control; however, SA increased significantly ascorbic acid content under salt stress compared with other treatments (Fig. 1 C).

\subsection{SA AND $\mathrm{KNO}_{3}$ MODULATE IAA, CK, ABA, AND GA3 LEVELS}

The application of treatments significantly in- creased IAA, CK, and GA3 levels, either under saltwater or freshwater, compared with controls (Fig. 2). Whereas the content of ABA increased under salt stress only, and no significant effect of treatment was observed under normal conditions. SA increased ABA and GA3 content significantly under salt stress (Fig. 2 C, D).

\subsection{SA AND $\mathrm{KNO}_{3}$ MODULATE THE PROTEIN PATTERN OF LEAVES}

The protein pattern of date palm leaves was determined according to the molecular mass $(\mathrm{KD})$ of protein bands affected by SA and $\mathrm{KNO}_{3}$ under freshwater and saltwater conditions by SDS-PAGE gel electrophoresis (Fig. 3). The leaf proteins in both controls were separated into five different polypeptides through acrylamide gels (Fig. 3). The control treatment with freshwater has a molecular mass of polypeptides 236.000, 132.072, $69.333,40.642$, and $34.389 \mathrm{KD}$, whereas control with salt water, had different molecular mass to three polypeptides $177.500,44.179$, and $30.090 \mathrm{KD}$. The application of SA showed five and six-band of proteins with fresh water and with saltwater, respectively, that differed in the molecular mass of one polypeptide compared to control with fresh water $28.232 \mathrm{KD}$. Whereas, SA with saltwater changed the molecular mass of two polypeptides compared to control with salt water 17.090 and 13.980 $\mathrm{KD}$ and showed six bands (Fig. 3). However, potassium application showed five bands of protein, whether with freshwater or with saltwater. One of the polypeptides 


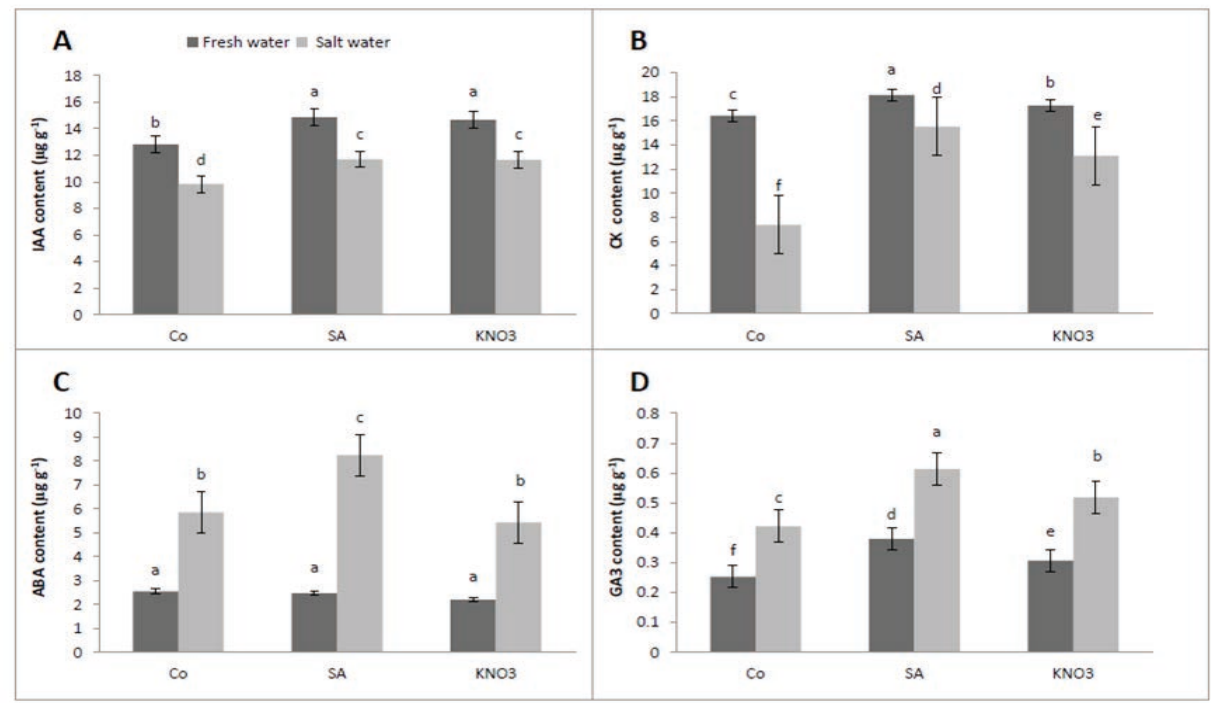

Figure 2: Salicylic acid and potassium nitrate effects on IAA (A), CK (B), ABA (C), and GA3 content (D) in leaves of date palm offshoots under irrigation with salt water or with fresh water. The means of five replicates \pm SE are presented. Bars with different letters are significantly different at $p \leq 0.05$ after a Duncan correction.

differed in the molecular mass compared to the treatment of potassium with fresh water $33.188 \mathrm{KD}$. In contrast, two polypeptides differed in the molecular mass compared to potassium with saltwater treatment 33.600 and 14.646 KD (Fig. 3).

\section{DISCUSSION}

Date palm offshoots give a few numbers of floral buds that turn into a cluster at the beginning of their transformation from the vegetative to the flowering phase under extreme conditions. The salicylic acidtreated plant accelerated flowering initiation in plants under the salinity conditions (Wada \& Takeno, 2013). An increase in the number of clusters observed after the application of SA (Fig. 1 A) was due to its effect on increase of carbohydrates to higher levels than the impact of salinity alone (Fig. $1 \mathrm{C}$ ). SA acts as an internal signal to regulate the physiological processes (Appu \& Muthukrishnan, 2014).

Desoky and Merwad (2015) reported that spraying the leaves of wheat plants with SA increased the soluble carbohydrate content. Carbohydrate content in the plant increased the chances of the axillary buds transformation into a floral bud (Dierck, 2016). The number of increased leaves reflected the increase in the number of clusters (Fig. 1B, A). Inducing flowering, when connected to salicylic acid, might be the consequence of the positive impact on plant development. It can be indirect as SA adjusts the synthesis and signaling pathways of other plant hormones, including gibberellin, auxin, and abscisic acid (Fig. 2). SA and $\mathrm{K}^{+}$ion have a role in cell division and stimulate secondary metabolism to produce antioxidants such as ascorbic acid. However, SA with saltwater increased AsA content (Fig. D). AsA is a primary co-factor in the synthesis of ethylene, gibberellic acid, and abscisic acid. Therefore, the endogenous level of AsA can affect the signaling of synthesis of those molecules (Anwar et al., 2018). Also, AsA is considered as an organic acid that stimulates the process of flowering (Akram et al., 2017)ascorbic acid (AsA. The high AsA content in plants supports a particular balance in preventing pigment damage and membrane injury (Costa et al., 2018). The antioxidant activity of ascorbate peroxidase and superoxide dismutase, and synthesis of special protein groups were increased by SA and AsA, together with salt stress (Al-Mayahi, 2016).

SA increased ABA and GA3 significantly under salt stress (Fig. 2 C, D). Salicylic acid rose IAA, CK and ABA levels, enhanced cell division in the apical meristem, and improved flowering of the plant (Sytar et al., 2019). In contrast, Alonso-Ramírez et al. (2009) reported that there was a cross-talk between SA and GA3 in Arabidopsis thaliana during abiotic stress conditions. GA3 induced flowering in early varieties of date palm (Cheruth et al., 2015). ABA has molecular effects on the downstream states of the autonomous biological pathway and, as such, improves the plant's capacity to encounter the change to flowering (Duncan et al., 2018).

The proteins are the final product of genetic pathways inside the plant cells that are created in light of cell 


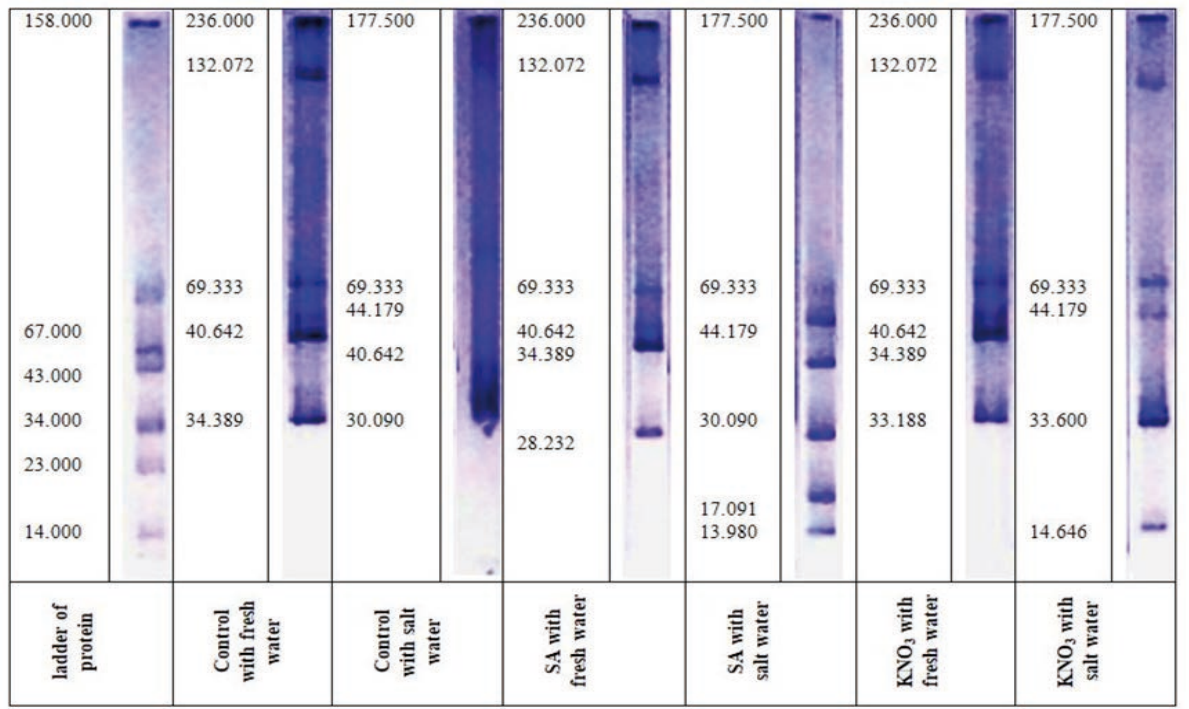

Figure 3: hematic diagrams of the electrophoretic protein pattern of date palm leaves with the molecular mass (KD) of protein bands affected by salicylic acid and potassium nitrate under freshwater and saltwater conditions.

needs and moved imbalances in some areas throughout entirely different stages of life and stress conditions (Razavizadeh, 2015)Brassica napus L.. Applications of $\mathrm{SA}$ and $\mathrm{K}^{+}$showed new protein bands with low molecular mass and the disappearance of other groups (Fig. 3). Salinity and SA induced de novo caused compilation of particular polypeptides and regulated the expression of salt-stress-tolerant proteins (Amirbakhtiar et al., 2019)which permits unrestricted use, distribution, and reproduction in any medium, provided the original author and source are credited. Salt stress is one of the major adverse environmental factors limiting crop productivity. Considering Iran as one of the bread wheat origins, we sequenced root transcriptome of an Iranian salt tolerant cultivar, Arg, under salt stress to extend our knowledge of the molecular basis of salinity tolerance in Triticum aestivum. RNA sequencing resulted in more than 113 million reads and about 104013 genes were obtained, among which 26171 novel transcripts were identified. A comparison of abundances showed that 5128 genes were differentially expressed due to salt stress. The differentially expressed genes (DEGs. In Arabidopsis thaliana and different other flowering plants, it was suggested that molecular mechanisms which include gibberellic acid regulate the LFY promoter (Blazquez, 1998). However, ABA-induced RNAbinding proteins SNF5 and FCA control flowering time and stress responses (Fahraji et al., 2014) kinetin and salicylic acid may increase yield of different crops due to reduction in stress induced inhibition of plant growth. Salicylic acid (SA. In this respect, SA and salinity conditions together induced high levels of GA3 and
ABA which caused synthesis of new isozymes of low molecular mass to form the new floral buds. These findings could facilitate understanding the mechanisms of flowering and salt-tolerance of the date palm.

\section{CONCLUSION}

Exogenous application of SA and $\mathrm{KNO}_{3}$ enhanced the biochemical mechanisms of flowering in the date palm through conferring adaptation to salinity stress and creating new isozyme. IAA, ABA, CK, and GA3 successfully increased the number of the cluster. Furthermore, these hormones in the plant under salinity conditions contribute to the process of flowering by the formation of specific proteins through the epigenetic pathway to promote the transformation of the offshoots into an adult plant. This study is the first, which highlighted the stimulative effect of $\mathrm{SA}$ and $\mathrm{KNO}_{3}$ on the flowering of the date palm.

\section{REFERENCES}

Akram, N.A., Shafiq, F. \& Ashraf, M. (2017). Ascorbic Acid-A Potential Oxidant Scavenger and Its Role in Plant Development and Abiotic Stress Tolerance. Frontiers in Plant Science, 8, 1-17. https://doi.org/10.3389/fpls.2017.00613

Al-Mayahi, Ahmed M. W. (2016). Influence of salicylic acid (SA) and ascorbic acid (ASA) on in vitro propagation and salt tolerance of date palm (Phoenix dactylifera 'Nersy'). Australian Journal of Crop Science, 10(7), 969-976. https:// doi.org/10.21475/ajcs.2016.10.07.p7640 
Allbed, A., Kumar, L., \& Shabani, F. (2017). Climate change impacts on date palm cultivation in Saudi Arabia. Journal of Agricultural Science, 155(8), 1203-1218. https://doi. org/10.1017/S0021859617000260

Alonso-Ramírez, A., Rodríguez, D., Reyes, D., Jiménez, J. A., Nicolás, G., López-Climent, M., \& Nicolás, C. (2009). Cross-talk between gibberellins and salicylic acid in early stress responses in Arabidopsis thaliana seeds. Plant Signaling and Behavior, 4(8), 750-751. https://doi.org/10.4161/ psb.4.8.9175

Amirbakhtiar, N., Ismaili, A., Ghaffari, M.R., Firouzabadi, F.N. \& Shobbar, Z.S. (2019). Transcriptome response of roots to salt stress in a salinity-tolerant bread wheat cultivar. Plant Physiology, 177, 475-489. https://doi.org/10.1371/ journal.pone.0213305

Anwar, A., Liu, Y., Dong, R., Bai, L., Yu, X. \& Li, Y. (2018). The physiological and molecular mechanism of brassinosteroid in response to stress: A review. Biological Research, 51, 1-15. https://doi.org/10.1186/s40659-018-0195-2

Appu, M., \& Muthukrishnan, S. (2014). Foliar Application of Salicylic Acid Stimulates Flowering and Induce Defense Related Proteins in Finger Millet Plants. Universal Journal of Plant Science, 2(1), 14-18. https://doi.org/10.13189/ ujps.2014.020102

Blazquez, M. A. (1998). Gibberellins Promote Flowering of Arabidopsis by Activating the LEAFY Promoter. The Plant Cell Online, 10(5), 791-800. https://doi.org/10.1105/ tpc.10.5.791

Cheruth, A. J., Kurup, S. S., \& Subramaniam, S. (2015). Variations in Hormones and Antioxidant Status in Relation to Flowering in Early, Mid, and Late Varieties of Date Palm (Phoenix dactylifera) of United Arab Emirates. The Scientific World Journal, 1, 1-8. https://doi. org/10.1155/2015/846104

Costa, S.F., Martins, D., Agacka-mo, M., Czubacka, A. \& Araújo, S.D.S. (2018). Strategies to Alleviate Salinity Stress in Plants. In V. Kumar et al. (eds.) Salinity Responses and Tolerance in Plants. pp. 307-337. https://doi.org/10.1007/9783-319-75671-4

Desoky, E.S.M. \& Merwad, A.R.M. (2015). Improving the Salinity Tolerance in Wheat Plants Using Salicylic and Ascorbic Acids. Journal of Agricultural Science, 7, 203-217. https://doi.org/10.5539/jas.v7n10p203

Dierck, R. (2016). Shoot branching: analysis of axillary bud outgrowth in Chrysanthemum morifolium. Ph.D. Thesis, Ghent University, Gent, Belgium pp,165.

Duncan, D.R., Phillips, G.C., Thorpe, T.A. \& Dai, W. (2018). Cellular \& Developmental Biology. Springer, pp. 135.

Elsadig, E.H., Aljuburi, H.J., Elamin, A.H.B. \& Gafar, M.O. (2017). Impact of organic manure and combination of N P K S, on yield, fruit quality and fruit mineral content of Khenazi date palm (Phoenix dactylifera L.) cultivar. Journal of Scientific Agriculture, 1, 335. https://doi. org/10.25081/jsa.2017.v1.848

Fahraji, S.S., Kheradmand, M.A. \& Mahdi, M. (2014). Effect of Salicylic acid on germination, leaf area, Shoot and root growth in crop plants. International Research Journal of Applied and Basic Sciences, 8, 1454-1458. https://doi. org/10.1007/978-3-319-14714-7_10
Farooq, M., Hussain, M., Wakeel, A. \& Siddique, K.H.M. (2015). Salt stress in maize: effects, resistance mechanisms, and management. A review. Agronomy for Sustainable Development, 35, 461-481. https://doi.org/10.1007/s13593015-0287-0

Khayyat, M., Jabbari, M., Fallahi, H.R. \& Samadzadeh, A. ( 2018). Effects of corm dipping in salicylic acid or potassium nitrate on growth, flowering, and quality of saffron. Journal of Horticultural Research, 26, 13-21. https://doi. org/10.2478/johr-2018-0002

Laemmli UK. (1970). Cleavage of structural proteins during the assembly of the head bacteriophage T4. Nature, 227, 680-685. https://doi.org/10.1038/227680a0

Lakudzala, D. D. (2013). Potassium Response in some Malawi Soils. International Letters of Chemistry, Physics and Astronomy, 13(2), 175-181. https://doi.org/10.18052/www. scipress.com/ILCPA.13.175

Luwe, M.W.F., Takahama, U. \& Heber, U. (1993). Role of ascorbate in detoxifying ozone in the apoplast of spinach (Spinacia oleracea L.) leaves. Plant Physiology, 101, 969-976. https://doi.org/10.1104/pp.101.3.969

Lymperopoulos, P., Msanne, J. \& Rabara, R. (2018). Phytochrome and Phytohormones: Working in Tandem for Plant Growth and Development. Frontiers in Plant Science, 9, 1-14. https://doi.org/10.3389/fpls.2018.01037

Moustafa A.R.A., Abdel-Hamid N.A., Abd El-Hamid A.A., ElSonbaty, S.M.R. \& Abd El-Naby, S.K.M. (2018). Improving fruit set, yield and fruit quality of khadrawi date palm cultivar. Arab Universities Journal of Agricultural Sciences, 26, 1461-1469. https://doi.org/10.21608/ajs.2018.34126

Razavizadeh, R. (2015). Protein pattern of canola (Brassica napus L.) changes in response to salt and salicylic acid in vitro. Biological Letters, 52(1-2), 19-36. https://doi. org/10.1515/biolet-2015-0012

Safar-Noori, M., Assaha, D. V. M. \& Saneoka, H. (2018). Effect of salicylic acid and potassium application on yield and grain nutritional quality of wheat under drought stress condition. Cereal Research Communications, 46(3), 558568. https://doi.org/10.1556/0806.46.2018.026

Shareef H. J., Jasim, A. M. \& Abass, M. F. (2017). Molecular Analysis of Anti-salinity Compounds on Date Palm offshoots (Phoenix dactylifera L.) cultivars using RAPD. Journal of Environmental Science, 6(February), 061-071.

Shareef, H. J. (2016). Enhancing Fruit Set and Productivity in Date Palm (Phoenix Dactylifera L.) Berhi Cultivar Using Boron and Potassium. Journal of Environmental Science, 5, 108-114.

Sytar, O., Kumari, P., Yadav, S., Brestic, M. \& Rastogi, A. (2019). Phytohormone Priming: Regulator for Heavy Metal Stress in Plants. Journal of Plant Growth Regulation, 38, 739-752. https://doi.org/10.1007/s00344-018-9886-8

Tamaoki, D., Seo, S., Yamada, S., Kano, A., Miyamoto, A., Shishido, H., Miyoshi, S., Taniguchi, S., Akimitsu, K. \& Gomi, K. (2013). Jasmonic acid and salicylic acid activate a common defense system in rice. Plant Signaling \& Behavior, 8, 8-10. https://doi.org/10.4161/psb.24260

Waadt, R., Hsu, P.K. \& Schroeder, J.I. (2015). Abscisic acid and other plant hormones: Methods to visualize distribu- 
tion and signaling. BioEssays, 37, 1338-1349. https://doi. org/10.1002/bies.201500115

Wada K. C. \& Takeno K. (2013). Salicylic Acid-Mediated Stress-Induced Flowering. In Hayat, S., Ahmad, A., \& Alyemeni, M.N. (eds.), Salicylic Acid (pp. 163-182) Springer Science+Business Media Dordrecht. https://doi. org/10.1007/978-94-007-6428-6_9

Yan, F., Zhou, H., Yue, M., Yang, G., Li, H., Zhang, S. \& Zhao, P. (2019). Genome-wide identification and transcriptional expression profiles of the f-box gene family in common walnut (Juglans regia L.). Forests, 10, 1-20. https://doi. org/10.3390/f10030275
Yemm, E.W., \& Willis, A.J. (1954). The estimation of carbohydrates in plant extracts by anthrone. Biochemical Journal, 57, 508-514. https://doi.org/10.1042/bj0570508

Zhang, Y., Lv, Y., Jahan, N., Chen, G., Ren, D. \& Guo, L. (2018a). Sensing of abiotic stress and ionic stress responses in plants. International Journal of Molecular Sciences, 19, 1-16. https://doi.org/10.3390/ijms19113298

Zhang, Z., Zhuo, X., Zhao, K., Zheng, T., Han, Y., Yuan, C. \& Zhang, Q. (2018b). Transcriptome Profiles Reveal the Crucial Roles of Hormone and Sugar in the Bud Dormancy of Prunus mume. Scientific Reports, 8, 1-15. https://doi. org/10.1038/s41598-018-23108-9 